\title{
Drug-Induced Modifications in Sexual Behavior and Open Field Locomotion of Male Rats
}

\author{
FRED I. LEAVITT ${ }^{2}$ \\ Department of Psychology, University of Michigan, Ann Arbor, Michigan 48104
}

(Received 2 January 1969)

\begin{abstract}
LEAvIT, F. I. Drug-induced modifications in sexual behavior and open field locomotion of male rats. PHYSIOL. BeHAv. $4(5) 677-683,1969$. - Several drugs were selected for sexual and open field behavioral testing, according to the following criteria: they are known synergists or antagonists of presumptive neurotransmitters; they modify behaviors thought to be related to sexual behavior; or they enjoy a popular reputation as aphrodisiacs in man. The drugs chosen were scopolamine, physostigmine, methamphetamine, cocaine, tranylcypromine, diazepam, cantharidin, and oxytocin. Scopolamine and diazepam disrupted sexual behavior, despite having differential effects on open field locomotion; locomotion was increased by scopolamine and unchanged by diazepam. Cocaine and methamphetamine increased locomotion, and in low doses were the only drugs to accelerate sexual performance. High doses of cocaine also increased locomotion, but had predominantly inhibitory actions on sexual performance. The other drugs were without significant effects on either behavior. The results are interpreted as indicating that activation of adrenergic pathways facilitates the sexual performance of male rats, and that alterations of cholinergic balance are disruptive. Open field activity modifications are not correlated with changes in sexual behavior.
\end{abstract}

Sexual behavior Open field locomotion Self-stimulation Adrenergic Cholinergic Aphrodisiacs Male rats

SEVERAL recent studies have been concerned with identification of the neurotransmitters which mediate sexual behavior. Bignami [4] systematically investigated the effects upon male rats of various antagonists of the neurotransmitter acetylcholine. All but adiphenine disrupted sexual behavior; the others, in order of decreasing potency, were scopolamine, benactyzine, atropine, and methylatropine. The central anticholinergic activities of the drugs follow the same pattern, with benactyzine differing from adiphenine only in that the latter does not penetrate the blood-brain barrier. The results confirm an earlier study by Soulairac [40], in which atropine disrupted the sexual behavior of male rats. However, Bignami's animals were used for 8 months, during which time they were tested with several different drugs. The procedure is questionable, since sexual behavior changes with both age and experience [21], and interactions between age and experimental conditions have been reported [21]. Thus, the temporal sequence in which the drugs were administered assumes considerable importance. Secondly, drug-induced behavioral changes often persist beyond a single test session, because of learning [41], placebo [16], or rebound [36] effects. Bignami's procedure is not entirely clear, but it appears that equivalent numbers of rats were tested with drug and with saline. Then a second drug was tested and the roles reversed for drugged and control subjects. The new controls might have differed from their comparison group simply because they alone had had prior exposure to the first drug. For example, rats which have previously been tested with chlorpromazine mount more frequently during saline sessions than rats previously tested with caffeine [41].

Bignami's rats did not have access to food or water during test sessions. This suggests a possible peripheral mechanism for the disruptive effects of anticholinergics; they inhibit salivary secretions, scopolamine more so than atropine, so that extreme dryness of the mouth results [12]. The subsequent discomfort might interfere with sexual responsiveness.

Soulairac did not state her schedule of drug treatments, so the criticisms raised against Bignami may also apply to her work. Other questionable aspects of her methodology relate primarily to establishment and maintenance of stable behavioral patterns. Most researchers give the experimental males several preliminary tests prior to drug administration; the males are habituated to the sex arenas prior to introduction of the females; full receptivity of the females during test sessions is assured by first observing them with experienced non-experimental males; subjects are tested during the dark phase of a regulated day-night cycle [4]. Failure to mention any of these procedures is distressing, especially since

\footnotetext{
${ }^{1}$ This research is based on a dissertation submitted to the University of Michigan in partial fulfilment for the requirements of the Ph.D. degree. The author was a trainee under USPHS Grant MH-10699-02, administered by Edward Domino. Supplies were purchased with funds from USPHS NIMH Grant MH-13253-02 to Stephen Glickman. I gratefully acknowledge Dr. Glickman's advice throughout the planning and writing. Frank Beach critically read this manuscript, and offered many valuable suggestions. Hormones were generously supplied by Dr. Preston Perlman of the Schering Corporation, Bloomfield, New Jersey.

${ }^{2}$ Now in the Dept. of Psychology, Williams College, Williamstown, Massachusetts, 01267.
} 
females were prepared with single injections $(20-100 \mu \mathrm{g})$ of estradiol benzoate, which Beach [2] has reported to be ineffective in inducing high levels of receptivity.

For many of the drugs employed, Soulairac administered the same dosage to all subjects, regardless of their body weight. Frequently only one dose level was investigated. She made no scoring distinction between mounts and intromissions, a procedure which has since been criticized [3]. Finally, her level of significance, $p=0.1$, is unacceptable by most current standards.

Bignami investigated the effects of nicotine, and Soulairac those of physostigmine. These drugs represent the other side of the cholinergic-anticholinergic coin. Nicotine had little effect upon copulatory behavior cxcept at doses which produce motor impairment. By contrast, $100 \mu \mathrm{g}$ doses of physostigmine produced severe decrements in the sexual performance of male rats. The latencies to ejaculation were prolonged, and the number of ejaculations per one-hour test decreased.

Soulairac's work with adrenergic drugs [40] is not easily systematized. Norepinephrine and large doses of epinephrine inhibited sexual behavior, whereas $50 \mu \mathrm{g} / \mathrm{kg}$ of epinephrine increased ejaculatory frequency. Iproniazid $(2.5 \mathrm{mg} / 100 \mathrm{~g} /$ day $)$ had an initial potentiating effect, but after 5 days of continuous treatment sexual behavior was impaired or abolished in all rats. The behavior returned to pre-drug levels after 14 days of continuous treatment. The response to amphetamine was biphasic; doses of $2 \mathrm{mg} / \mathrm{kg}$ initially increased ejaculatory frequency while shortening postejaculation refractory periods, but sexual behavior was frequently disrupted during later administrations. Bignami [4], too, reported an acceleration of sexual behavior after small $(0.5 \mathrm{mg} / \mathrm{kg})$ doses of amphetamine, but at $2 \mathrm{mg} / \mathrm{kg}$ changes were in the opposite direction from those described by Soulairac. Differences in route of administration (i.p. for Soulairac, s.c. for Bignami), or strain differences in susceptibility may account for the disparate results.

Several of the drugs used in the present study modify cholinergic or adrenergic functioning. Three substances reputed to possess aphrodisiac properties, viz., cantharidin, cocaine, and methamphetamine, were also tested, as was the neurohypophyseal hormone oxytocin. The latter drug facilitates several aspects of sexual performance in male rabbits [24].

Administration of drugs in doses which affect locomotor activity or responsiveness to electrical stimulation of reward sites in the brain might be expected to induce changes in sexual performance. Therefore, some drugs were selected on the basis of their ability to modify these behaviors.

\section{MATERIALS AND METHODS}

\section{Subjects}

The male subjects used in this experiment were hooded rats of the Long-Evans strain, obtained from Simonsen's Laboratories, Inc., Gilroy, California. They were approximately 70 days old and weighed $300 \mathrm{~g}$ at the start of the experiment. The females were $200 \mathrm{~g}$ albino rats of the Sprague-Dawley strain, supplied by Spartan Research Animals, Inc. of Haslett, Michigan. The females were housed in group cages, the males individually. Food and water were available at all times. At least one week prior to their first screening test, all males were placed on a reversed $12 \mathrm{hr}$ on, $12 \mathrm{hr}$ off light cycle. All tests were conducted during the first $4 \mathrm{hr}$ of the dark portion of the cycle, in a room illuminated by a single $25 \mathrm{~W}$ bulb suspended from the ceiling.

Eighty males were randomly assigned to 10 different groups of 8 rats each. Rats from this initial grouping which died during the course of the experiment were replaced. When replacement subjects died no further substitutions were made. Thus, the final $\mathrm{N}$ in the cantharidin group is 4 because replacements died. A single animal and its replacement in the physostigmine group died.

\section{Apparatus}

The arenas used for sex-testing were rectangular boxes measuring approximately $24 \times 12 \times 12$ in. with clear glass front panels. Food pellets were scattered along the floor and water was available through a drinking spout on the side of the cage. The presence of food and water was a precautionary measure designed to minimize potentially disruptive effects due to drug-induced changes in hunger or thirst. Mounts, intromissions, and ejaculations were recorded on a Rustrak 4-channel event recorder. Animals were also tested in a $4 \times 4 \mathrm{ft}$ field with gray wooden sides $1 \mathrm{ft}$ in height. A sheet of while oilcloth ruled into $161-\mathrm{ft}$ squares comprised the floor of the cage.

\section{Procedure}

Females were brought into estrus by s.c. injections of $0.1 \mathrm{mg}$ of estradiol benzoate followed $72 \mathrm{hr}$ later by $1.0 \mathrm{mg}$ of progesterone. The progesterone was administered $3 \mathrm{hr}$ prior to testing. The receptivity of the females was judged by placing them with experienced non-experimental males, and only fully receptive females were used. They were rested for a minimum of two weeks between mating tests.

Males were given sexual experience by testing them at weekly intervals until they achieved two ejaculations within a test session for 3 consecutive weeks. The third session was preceded by injection of isotonic saline.

Four males were tested simultaneously, 2 each under drug and saline conditions. After being injected, the animals were returned to their cages for a predetermined period of time that varied with each drug (see Table 1), then adapted to the testing arena for $5 \mathrm{~min}$ before the female was introduced. Behavior was recorded up to and including the first intromission following the second ejaculation. After the autogenital grooming which typically follows copulation had subsided, the males were removed. Tests were also terminated if $1 \mathrm{hr}$ elapsed without an ejaculation, or $90 \mathrm{~min}$ without 2 . These time limits are considerably longer than have been used in most recent research, and they resulted in the inclusion of many subjects of only moderate sexual vigor. Thus, facilitatory drug effects were not likely to be masked because subjects were already performing at maximal levels. Such a possibility was offered by Bignami [4] to account for the small effects he obtained with amphetamine.

The animals were given 8 tests of sexual performance followed by 410 -min tests in the open field. The inter-trial interval was 1 wk for all tests. The open field tests were conducted at the same time of day and under the same conditions as the sex tests. Animals were placed in the corner of the field nearest to the experimenter, and a count was made of the number of squares entered during the subsequent 10 -min period. The criterion for entry of a square was that both forepaws were in it. 
TABLE 1

Drugs Used in the Present Experiment

\begin{tabular}{|c|c|c|c|c|}
\hline Drug & $\begin{array}{l}\text { Dosage as } \\
\text { salt, } \mathrm{mg} / \mathrm{kg}\end{array}$ & $\begin{array}{l}\text { Time between } \\
\text { injection and } \\
\text { testing (min) }\end{array}$ & $\begin{array}{l}\text { Approximate latency and duration } \\
\text { of action (min) }\end{array}$ & $\begin{array}{l}\text { Dosages used in study cited } \\
\text { in previous column }(\mathrm{mg} / \mathrm{kg})\end{array}$ \\
\hline $\begin{array}{l}\text { scopolamine } \\
\text { hydrobromide }\end{array}$ & 0.3 and 0.9 & 20 & $\begin{array}{l}15 \text { and } 20 \text {, for disruption of sexual } \\
\text { behavior in male rats [4] }\end{array}$ & 0.1 and 0.5 \\
\hline $\begin{array}{l}\text { physostigmine } \\
\text { salicylate }\end{array}$ & 0.2 and 0.8 & 5 & $\begin{array}{l}15 \text { and unknown, for reduced rates of } \\
\text { self-stimulation in male rats [20] }\end{array}$ & 0.1 and 0.2 \\
\hline $\begin{array}{l}\text { methamphetamine } \\
\text { hydrochloride }\end{array}$ & 0.75 and 2.25 & 5 & $\begin{array}{l}\text { immediately and } 60 \text {, for increased self- } \\
\text { stimulation in male rats [33] }\end{array}$ & 0.5 \\
\hline $\begin{array}{l}\text { cocaine } \\
\text { hydrochloride }\end{array}$ & 10.0 and 30.0 & 20 & $\begin{array}{l}\text { immediately and } 30 \text {, for increased loco- } \\
\text { motor activity of male mice [38] }\end{array}$ & $3.0-30$ \\
\hline tranylcypromine & 2.0 and 4.0 & 120 & $\begin{array}{l}120 \text { and } 60, \text { for increased self-stimula- } \\
\text { tion in male rats [33] }\end{array}$ & 2.0 \\
\hline diazepam & 2.5 and 5.0 & 20 & $\begin{array}{l}\text { less than } 24 \text { and more than } 48 \text {, for } \\
\text { increased self-stimulation in rats [31] }\end{array}$ & 5.0 \\
\hline $\begin{array}{l}\text { synthetic } \\
\text { oxytocin }\end{array}$ & $\begin{array}{l}0.5 \mathrm{IU} / \mathrm{kg} \text { and } \\
1.0 \mathrm{IU} / \mathrm{kg}\end{array}$ & 5 & $\begin{array}{l}\text { immediately and } 30, \text { for improvement in } \\
\text { sexual performance of male rabbits [24] }\end{array}$ & $0.15-0.60 \mathrm{IU} / \mathrm{kg}$ \\
\hline cantharidin & 0.67 & 20 & $\begin{array}{l}\text { immediately for occurrence of pain in } \\
\text { young boy; } 30 \text { for appearance of blebs } \\
\text { on skin; several weeks for remission of } \\
\text { all symptoms [6] }\end{array}$ & unknown \\
\hline
\end{tabular}

\section{Scoring}

The following measures were recorded: Sexual Contact Latency (SCL) - the time in sec from introduction of the female to the male's first mount, with or without intromission; Intromission Latency (IL)-the time in sec from introduction of the female to the first successful intromission; Mount Frequency (MF)-the number of mounts without intromission within a given series (the term "series" refers to the sequence of sexual behaviors which is terminated by an ejaculation); Intromission Frequency (IF)-the number of intromissions within a given series; Interintromission Interval (III)-the average interval in sec between mounts with intromission in the same series; First Total Ejaculation Latency $\left(E L_{1}\right)$-the time in sec from introduction of the female to the first ejaculation; Second Total Ejaculation Latency $\left(\mathrm{EL}_{\mathbf{2}}\right)$ the time in sec between the first and second ejaculations; Postejaculatory Interval (PEI)-the time in sec from one ejaculation to the first intromission of the next series.

The open field measure (OF) was number of squares entered per $10 \mathrm{~min}$ period.

\section{Schedules of Treatment}

Within a group, each male was tested at two dose levels with a single drug. The cantharidin subjects were initially tested at two dose levels, but all subjects which received 2.01 $\mathrm{mg} / \mathrm{kg}$ died shortly thereafter. The remaining subjects and the replacements were therefore tested only at the lower dose $(0.67 \mathrm{mg} / \mathrm{kg})$. For each drug 2 rats were assigned to each of the following sequences of administration, where $S=$ isotonic saline, $\mathbf{H}=$ higher dose of drug, and $\mathrm{L}=$ lower dose: 1 .
S-L-S-L-S-H-S-H. 2. S-H-S-H-S-L-S-L. 3. L-S-L-S$\mathrm{H}-\mathrm{S}-\mathrm{H}-\mathrm{S}$. 4. H-S-H-S-L-S-L-S. One group of 8 rats received only saline throughout the testing.

For the open field tests the sequences were abbreviated to: 1. S-L-S-H. 2. S-H-S-L. 3. L-S-H-S. 4. H-S-L-S.

\section{Drug Preparations, Routes of Administration, and Dosages}

All drugs were injected i.p. The dosages correspond with those used by previous investigators to modify behavior in various ways (see Table 1). Table 1 also presents drug preparations, intervals between administration and testing, and approximate latencies and durations of action. On saline days the rats were weighed and then injected with the same volumes of saline as they would have received of drug. Volumes injected never exceeded $1 \mathrm{~cm}^{3}$.

\section{Analysis of Results}

There are many missing values under most drug treatments, as a result of drug disruption of sexual behavior. Procedures for replacing missing values for analysis of variance are not appropriate for the purpose of this experiment. Therefore, the randomization test for matched pairs [37] was employed to evaluate differences between saline, low dose, and high dose, for all measures listed above. Significance tests were computed only when at least 6 animals under each condition successfully mated. Approximately 200 separate comparisons were made, of which 10 would be expected to be significant at $p=0.05$ by chance alone. The data for the saline group were subjected to a trend analysis. 
RESULTS

Means of the various behavioral measures were obtained for each animal under each condition of testing; only those trials in which 2 ejaculations were achieved are included in the computations. The means of these individual subject means were then obtained, and are presented in Tables 2-6. The Tables are organized so that sexual latency measures are grouped together, as are rate and frequency measures. The tables also indicate open field locomotion scores.

The results for each of the groups are presented below. Each section commences with an indication of the number of failures to mate under saline, lower dose, and higher dose condition, followed by a presentation of significant differences between the conditions on the various indices of sexual behavior. Strong trends are noted when they are of special interest, as are instances when no tests of significance were made because of reduced Ns due to failures to mate. The open field data are then considered. Finally, mention is made of obvious qualitative behavioral changes under any of the conditions.

\section{Scopolamine}

Rats in the scopolamine group underwent a total of 32 saline trials. Of these, 4 were terminated because of failure to achieve 2 ejaculations within the prescribed time limit. By contrast, out of 16 tests each at 0.3 and $0.9 \mathrm{mg} / \mathrm{kg}$, there were 12 and 13 failures, respectively. Since fewer than $\frac{1}{2}$ of the animals copulated under drug conditions, no tests of significance were made. The only obvious trend was toward increased MF during successful scopolamine trials. MF was larger in series 2 than in series 1 with both doses of scopolamine, a pattern which was not observed under any other conditions.

During sex tests, most of the rats which were injected with scopolamine lay passively in a corner of the test arena for the duration of the sessions. This behavior was in marked contrast to that observed in the open field, where they were significantly more active than on control days.

\section{Physostigmine}

The only 4 failures to mate in the physostigmine group were at $0.8 \mathrm{mg} / \mathrm{kg}$, a dose which significantly increased SCL. The other latency measures-IL, EL, and PEI-were also increased, although the difference did not reach significance in the case of IL. However, the shortest PEIs were recorded after $0.2 \mathrm{mg} / \mathrm{kg}$.

The mean III was increased by physostigmine, significantly so for the series 2 comparison between $0.8 \mathrm{mg} / \mathrm{kg}$ and saline. Both doses reduced IF, the effect reaching significance at $0.8 \mathrm{mg} / \mathrm{kg}$ in series 1 , and $0.2 \mathrm{mg} / \mathrm{kg}$ in the second series. All open field comparisons were significant; activity was highest during saline sessions and least following treatment with $0.8 \mathrm{mg} / \mathrm{kg}$. Rats treated with the high dose frequently salivated, and made continuous jaw (swallowing?) movements. They were very sluggish, frequently remaining motionless for the entire test session.

\section{Methamphetamine}

Two rats failed to mate on both occasions following administration of $2.25 \mathrm{mg} / \mathrm{kg}$ methamphetamine. All other trials of this group were successfully completed. The pattern observed following nondisruptive doses of methamphetamine was an acceleration of sexual activity. Latency measures
TABLE 2

Effects of Physostigmine on Male Rat Sexual Behavior AND OPEN FIELD LOCOMOTION

\begin{tabular}{|c|c|c|c|}
\hline & $\begin{array}{c}\text { Saline } \\
(\mathrm{N}=7)\end{array}$ & $\begin{array}{c}0.2 \mathrm{mg} / \mathrm{kg} \\
(\mathrm{N}=7)\end{array}$ & $\begin{array}{c}0.8 \mathrm{mg} / \mathrm{kg} \\
(\mathrm{N}=-6)\end{array}$ \\
\hline \multicolumn{4}{|l|}{ Sex Scores } \\
\hline Failures to mate & $0 / 28$ & $0 / 14$ & $4 / 14$ \\
\hline \multicolumn{4}{|l|}{ Latency Measures } \\
\hline Median SCL & 11.5 & 8.5 & $471.9 \mathrm{~b}$ \\
\hline Median IL & 23.5 & 119.6 & 487.1 \\
\hline $\mathrm{EL}_{1}$ & 749.9 & 738.1 & $1150.8 \mathrm{a}, \mathrm{b}$ \\
\hline $\mathrm{EL}_{2}$ & 563.1 & 525.2 & 684.9 \\
\hline $\mathrm{PEI}_{1}$ & 340.4 & 334.8 & 435.7 \\
\hline $\mathrm{PEI}_{2}$ & 431.9 & $402.1_{\mathrm{a}}$ & $452.7 \mathrm{~b}$ \\
\hline \multicolumn{4}{|l|}{ Rate Measures } \\
\hline $\mathrm{III}_{1}$ & 61.3 & 69.8 & 106.4 \\
\hline $\mathrm{III}_{2}$ & 49.5 & 89.4 & $67.3_{a}$ \\
\hline \multicolumn{4}{|l|}{ Frequency measures } \\
\hline $\mathrm{MF}_{1}$ & 8.6 & 10.5 & 6.1 \\
\hline $\mathrm{MF}_{2}$ & 3.5 & 4.1 & 3.4 \\
\hline $\mathrm{IF}_{1}$ & 9.3 & 8.0 & $6.4 \mathrm{a}$ \\
\hline$I F_{2}$ & 4.6 & $3.5_{\mathrm{a}}$ & 6.1 \\
\hline Open Field Scores & s 60.8 & $32.3 \mathrm{a}$ & $9.3_{\mathrm{a}, \mathrm{b}}$ \\
\hline
\end{tabular}

The subscripts 1 and 2 refer to series 1 and 2 . The $\mathbf{N}$ for each condition is the number of subjects which completed at least one successful sex test under that condition. The Ns for open field data include subjects which failed in the sex tests, and are equal to the saline Ns in all cases. Lower-case indicated $p \leqq 0.05$, uppercase $\mathrm{p} \leqq 0.01$. $\mathrm{a}, \mathrm{A}=$ drug $v s$ saline; $\mathrm{b}, \mathrm{B}=$ low dose $v s$ high dose. Times are given in sec. These conventions are followed in Tables 3-6.

were all shortened by the drug, although only in the case of IL was the difference significant (saline $v s 2.25 \mathrm{mg} / \mathrm{kg}$ ). Higher doses of the drug significantly increased both MF and IF. The strongest effect of methamphetamine was on open field locomotion.

\section{Cocaine}

Rats in the cocaine group failed to mate 3 times during saline sessions, and once each at 10 and $30 \mathrm{mg} / \mathrm{kg}$. The effects of higher and lower doses of cocaine, for most of the indices of sexual activity, were in opposite directions. At $10 \mathrm{mg} / \mathrm{kg}$, cocaine facilitated sexual behavior; III, PEI, and EL in both series were shortened significantly. All of the changes but $\mathrm{PEI}_{2}$ were reversed at $30 \mathrm{mg} / \mathrm{kg}$. The higher dose significantly increased MF.

Unlike the changes in sexual behavior, there was no reversal of the cocaine effect on open field locomotion; activity was increased by both doses.

\section{Tranylcypromine}

There was a single failure to mate in the tranylcypromine group, that during a saline session. The only significant difference in sexual behavior or open field scores is that rats treated with $4.0 \mathrm{mg} / \mathrm{kg}$ had fewer intromissions in series 1 than when given saline. 
TABLE 3

Effects of Methamphetamine on Male Rat Sexual Behavor and Open Field locomotion. See Table 2 for Explanation OF SYMBOLS

\begin{tabular}{lccc}
\hline & $\begin{array}{c}\text { Saline } \\
(\mathrm{N}=8)\end{array}$ & $\begin{array}{c}0.75 \mathrm{mg} / \mathrm{kg} \\
(\mathrm{N}=8)\end{array}$ & $\begin{array}{c}2.25 \mathrm{mg} / \mathrm{kg} \\
(\mathrm{N}=6)\end{array}$ \\
\hline Sex Scores & & & \\
Failures to mate & $0 / 32$ & $0 / 16$ & $4 / 16$ \\
Median SCL & 11.9 & 8.2 & 7.2 \\
Median IL & 89.1 & 12.1 & $9.2 \mathrm{a}$ \\
EL & 605.0 & 589.3 & 591.8 \\
EL, & 594.1 & 709.8 & 612.9 \\
PEI $_{1}$ & 396.6 & 359.9 & 365.3 \\
PEI $_{2}$ & 464.6 & 409.7 & 417.4 \\
& & & \\
Rate Measures & & & \\
III $_{1}$ & 64.0 & 67.8 & 51.9 \\
III $_{2}$ & 51.2 & 51.6 & 51.1 \\
MF $_{1}$ & 4.9 & 3.9 & 11.4 \\
MF, $_{\text {IF }}$ & 1.7 & 2.1 & $7.3_{\mathrm{a}}$ \\
IF $_{2}$ & 8.7 & 8.2 & $12.6_{\mathrm{a}, \mathrm{b}}$ \\
Open Field Scores $_{2}$ & 43.9 & 94.9 & 5.5 \\
\hline
\end{tabular}

Diazepam

Administration of diazepam in the dose of $5.0 \mathrm{mg} / \mathrm{kg}$ disrupted sexual behavior in 13 of 16 tests. Four of 16 tests were unsuccessfully concluded at $2.5 \mathrm{mg} / \mathrm{kg}$, and 3 of 32 saline trials. Statistical comparisons were made only between saline and $2.5 \mathrm{mg} / \mathrm{kg}$. The most dramatic effect was a very large increase in MF, especially marked in series 1. Diazepam had an unusual effect on intromissions; IF was significantly

TABLE 4

Effects of Cocaine on Male Rat Sexual Behavior and Open Field locomotion. See Table 2 for Explanation or SYMBols

\begin{tabular}{|c|c|c|c|}
\hline & $\begin{array}{l}\text { Saline } \\
(\mathbf{N}=8)\end{array}$ & $\begin{array}{c}10.0 \mathrm{mg} / \mathrm{kg} \\
(\mathrm{N}=8)\end{array}$ & $\begin{array}{l}30.0 \mathrm{mg} / \mathrm{kg} \\
(\mathrm{N}=8)\end{array}$ \\
\hline $\begin{array}{l}\text { Sex Scores } \\
\text { Failures to mate }\end{array}$ & $3 / 32$ & $1 / 16$ & $1 / 16$ \\
\hline $\begin{array}{l}\text { Latency Measures } \\
\text { Median SCL } \\
\text { Median IL } \\
\text { EL_ }_{1} \\
\text { EL, }_{2} \\
\text { PEI }_{1} \\
\text { PEI }_{2}\end{array}$ & \begin{tabular}{r|}
16.0 \\
67.7 \\
859.7 \\
581.3 \\
381.8 \\
466.6
\end{tabular} & $\begin{array}{c}31.0 \\
70.2 \\
586.2_{\mathrm{a}} \\
431.0_{\mathrm{A}} \\
330.5_{\mathrm{a}} \\
390.7_{\mathrm{A}}\end{array}$ & $\begin{array}{c}30.0^{0} \\
275.0^{-0} \\
1020.9_{\mathrm{B}} \\
616.9_{\mathrm{B}} \\
408.0_{\mathrm{B}} \\
452.7_{\mathrm{b}}\end{array}$ \\
\hline $\begin{array}{l}\text { Rate Measures } \\
\text { III }_{1} \\
\text { III }_{2}\end{array}$ & $\begin{array}{l}79.3 \\
50.1\end{array}$ & $\begin{array}{l}62.4 \mathrm{a} \\
34.6\end{array}$ & $\begin{array}{l}90.4 \mathrm{a}, \mathrm{b} \\
61.3_{\mathrm{A}, \mathrm{B}}\end{array}$ \\
\hline $\begin{array}{l}\text { Frequency Measure } \\
\mathrm{MF}_{1} \\
\mathrm{MF}_{8} \\
\mathrm{IF}_{1} \\
\mathrm{IF}_{\mathbf{2}}\end{array}$ & $\begin{array}{r}10.4 \\
6.9 \\
10.3 \\
5.5\end{array}$ & $\begin{array}{l}7.6 \\
6.9 \\
9.8 \\
5.3\end{array}$ & $\begin{array}{c}21.3_{\mathrm{A}, \mathrm{B}} \\
14.7_{\mathrm{B}} \\
9.2 \\
5.0\end{array}$ \\
\hline Open Field Scores & 46.6 & $75.1_{\mathrm{A}}$ & $117.5_{\mathrm{A}}$ \\
\hline
\end{tabular}

reduced in the first series, but increased, also significantly, in series 2. The shift occurred in all rats tested. IL, III, and PEI were all increased by diazepam. There was a nonsignificant decrease in open field locomotion at $5.0 \mathrm{mg} / \mathrm{kg}$.

\section{TABLE 5}

Effects of Diazepam on Male Rat Sexual Behavior and Open Field locomotion. SeE Table 2 for Explanation of SYMBols

\begin{tabular}{|c|c|c|c|}
\hline & $\begin{array}{c}\text { Saline } \\
(\mathrm{N}=8)\end{array}$ & $\begin{array}{c}2.5 \mathrm{mg} / \mathrm{kg} \\
(\mathrm{N}=7)\end{array}$ & $\begin{array}{c}5.0 \mathrm{mg} / \mathrm{kg} \\
(\mathrm{N}=2)\end{array}$ \\
\hline $\begin{array}{l}\text { Sex Scores } \\
\text { Failures to mate }\end{array}$ & $3 / 32$ & $4 / 16$ & $13 / 16$ \\
\hline $\begin{array}{l}\text { Latency Measures } \\
\text { Median SCL } \\
\text { Median IL } \\
\text { EL }_{1} \\
\mathrm{EL}_{2} \\
\text { PEI }_{1} \\
\text { PEI, }_{1}\end{array}$ & $\begin{array}{r}15.7 \\
67.4 \\
782.3 \\
765.4 \\
416.9 \\
479.6\end{array}$ & $\begin{array}{r}11.6 \\
324.1_{\mathrm{A}} \\
1473.1_{\mathrm{a}} \\
960.8_{\mathrm{a}} \\
563.6_{\mathrm{a}} \\
547.6_{\mathrm{a}}\end{array}$ & $\begin{array}{r}7.5 \\
437.4 \\
911.3 \\
875.3 \\
373.6 \\
512.5\end{array}$ \\
\hline $\begin{array}{l}\text { Rate Measures } \\
\text { III }_{1} \\
\text { III, }_{2}\end{array}$ & $\begin{array}{l}67.7 \\
56.7\end{array}$ & $\begin{array}{c}108.3_{\mathrm{a}} \\
65.1\end{array}$ & $\begin{array}{l}105.0 \\
109.8\end{array}$ \\
\hline $\begin{array}{l}\text { Frequency Measures } \\
\mathrm{MF}_{1} \\
\mathrm{MF}_{2} \\
\mathrm{IF}_{1} \\
\mathrm{IF}_{2} \\
\text { Open Field Scores }\end{array}$ & $\begin{array}{r} \\
10.5 \\
5.6 \\
11.8 \\
5.8 \\
58.4\end{array}$ & $\begin{array}{r}52.0_{\mathrm{A}} \\
19.3_{\mathrm{a}} \\
8.2_{\mathrm{a}} \\
6.4_{\mathrm{A}} \\
62.5\end{array}$ & $\begin{array}{r}37.0 \\
46.8 \\
8.0 \\
5.5 \\
40.3\end{array}$ \\
\hline
\end{tabular}

TABLE 6

Sexual Behavior and Open Field Behavior of Male Rats Treated WrTh Saline

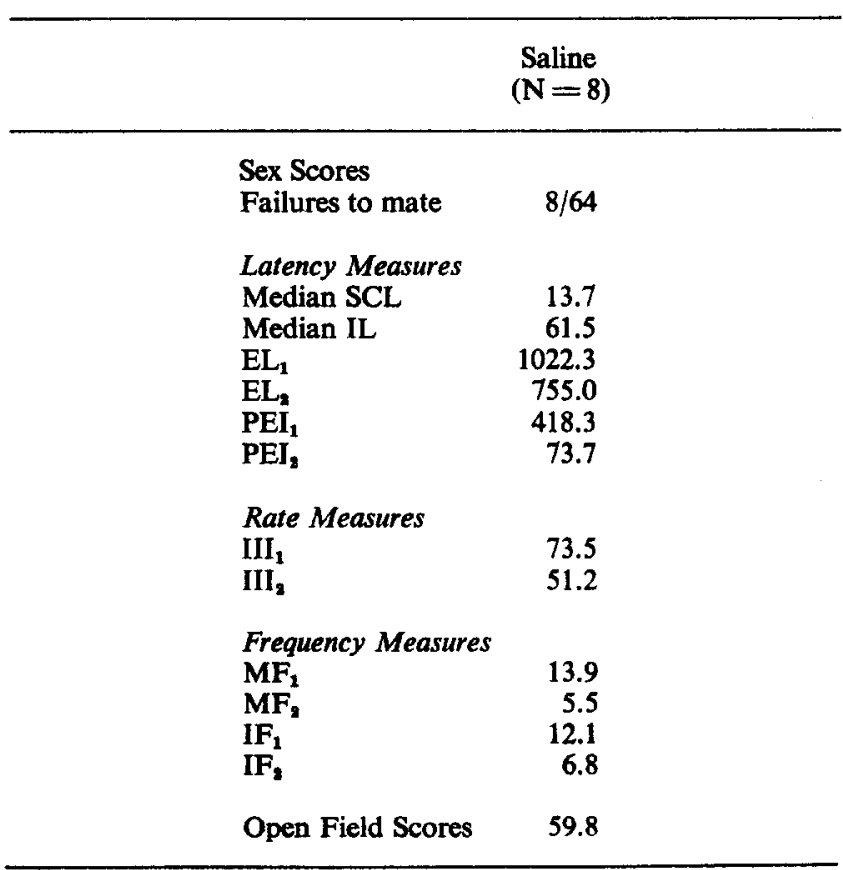




\section{Cantharidin}

Eight of the cantharidin rats died during the course of testing, leaving only 4 animals which completed the 8 sexual behavior trials. Of the 16 trials each with saline and cantharidin, there were 1 and 3 failures to mate, respectively. No discernible trends were observed in the data of the 4 animals; on none of the indices were the differences between saline and cantharidin sessions in the same direction for all subjects.

\section{Oxytocin}

The failures to mate in this group were 7 of 32,5 of 16 , and 4 of 16 , for saline, $0.5 \mathrm{IU} / \mathrm{kg}$, and $1.0 \mathrm{IU} / \mathrm{kg}$ respectively. There were no significant differences on any of the indices in this group, nor were there any apparent trends.

\section{Saline}

Eight of the saline trials resulted in failure to mate. The trials were organized into blocks of two, and then trend analyses were run for each of the indices used. There were no significant trends.

\section{DISCUSSION}

\section{Comparison of Present Study with Previous Research}

In spite of several methodological differences between the present experiment and earlier ones in which the same dependent and independent variables were studied, the results correspond well. Scopolamine and physostigmine have previously been reported to inhibit sexual behavior $[4,40]$, and the trend here toward reduced latencies of sexual reactivity in methamphetamine-treated rats closely parallels the findings with amphetamine [4]. Melin and Kihlstrom's report [24] of an improvement in the sexual performance of male rabbits injected with oxytocin was not confirmed, however. Differences in species, route of administration (i.v. vs i.p.), dosage (0.15-0.60 IU vs $0.5-1.0 \mathrm{IU} / \mathrm{kg}$ ), or method of measurement (ejaculation into artificial vagina $v s$ testing with live female) may account for the discrepant results.

The open field data are also compatible with the existent literature. Cocaine, methamphetamine, and scopolamine have been reported to increase locomotor activity $[25,27,38]$, and diazepam and tranylcypromine to have little effect $[23,35]$.

\section{The Neurotransmitters Involved in Sexual Behavior}

The cholinergic system. Both Bignami's data [4] and the present results suggest that anticholinergic drugs inhibit sexual behavior in male rats. Physostigmine, which promotes cholinergic functioning, has a similar effect. Perhaps all modifications of cholinergic functioning in rats interfere with sexual behavior. Bignami has proposed that a central mechanism is responsible.

The adrenergic system. Cocaine and methamphetamine accelerated sexual performance, thus extending earlier observations with amphetamine and LSD [4]. All four are adrenergic drugs which have predominantly central effects. Epinephrine, which acts at peripheral as well as central adrenergic sites, also potentiates sexual behavior at some doses [40]. Tranylcypromine had no effects on either sexual performance or locomotion, a result which accords with the observation [32] that MAO inhibitors "produce little or no change in the apparent behavior or attitude of laboratory animals".
Work with adrenergic blockers and depletors complements the abovementioned findings. Chlorpromazine interferes with sexual behavior in male rats [41], and men treated with the antiadrenergic drugs guanethidene, thioridazine, on chlorprothixene frequently report inability to ejaculate [10, $19,26]$. The transient sympathomimetic effects which are occasionally seen with reserpine [28] may account for its short-term improvement of the sexual performance of male rats [39], whereas the sexual inhibition after chronic administration [13] would be consonant with its depletor action.

Although the sites at which adrenergic drugs act to accelerate sexual behavior cannot be stated with certainty, several studies suggest that they are central. Thus, Hess [17] has elicited sympathetic responses such as piloerection, mydriasis, increased blood pressure, and facilitation of spinal reflexes from electrical stimulation of the posterior hypothalamus of unanesthetized cats; under different conditions, stimulation of the same structure in rats and squirrel monkeys has produced erection, ejaculation, and actual copulation $[8,15]$. Moreover, castration modifies concentrations of norepinephrine and dopamine in the anterior hypothalamus of male rats [11], and increases turnover rate of brain norepinephrine [1].

\section{Self-stimulation and Sexual Behavior}

Several investigators $[5,18,29]$ have demonstrated a relationship between rate of bar pressing for electrical stimulation of positively reinforcing brain sites, and hunger and thirst drives. Self-stimulation rate also varies with phase of the estrus cycle in female rats, being maximal during the period of heat [34]. Olds [29] showed that for some hypothalamic probes, the self-stimulation rate of male rats declines after castration and can be restored by androgen replacement therapy. Similar findings have since been reported [7, 15]. Copulation has been induced in male rats by electrical stimulation of sites which also supported self-stimulation $[7,8]$. Herberg [15] observed that seminal ejaculation often follows electrical stimulation of positively reinforcing sites in rats.

Of the 4 drugs used in the present study which have been previously shown to augment self-stimulation rates, cocaine and methamphetamine both facilitated sexual behavior, tranylcypromine was without effect, and diazepam was inhibitory. Reference has been made to the inactivity of tranylcypromine with respect to most behaviors. Diazepam may prolong the latencies to intromission and ejaculation because it depresses spinal reflexes [35]; Hart [14] has shown that the mechanisms for intromission and ejaculation in rats are organized within the spinal cord. In many respects the diazepam-treated rats appeared highly motivated sexually; SCL was less than on control days, and MF was markedly elevated.

Physostigmine depresses self-stimulation rates in rats [20], and is disruptive of sexual behavior. Scopolamine lowers current thresholds for maintenance of self-stimulation, but the results have been explained in terms of the increased resistance to extinction which scopolamine confers, rather than to changes in the reinforcing value of the stimulation per se [9].

There is additional pharmacological support for the notion that self-stimulation rate and sexual performance covary. Reserpine, chlorpromazine, and morphine all depress rates of self-stimulation as well as mating behavior [13, 30, 36, 41]. 
LSD was tested at $200 \mu \mathrm{g}$ [reported in 30] for its effects on self-stimulation; at this dose, which impairs sexual behavior [4], stimulation rate declined.

The results of tests with stimulant drugs are especially suggestive. Neither strychnine nor nicotine potentiate sexual performance [4], but caffeine does [41]. It is interesting to note that the drugs are similarly aligned with respect to their effects on self-stimulation [30].

\section{REFERENCES}

1. Anton-Tay, F. and R. J. Wurtman. Norepinephrine: turnover in rat brains after gonadectomy. Science 159: 1245, 1968.

2. Beach, F. A. Importance of progesterone to induction of sexual receptivity in spayed female rats. Proc. Soc. exp. Biol. Med. 51: 369-371, 1942.

3. Bermant, G., S. E. Glickman and J. Davidson. Effects of limbic lesions on copulatory behavior of male rats. J. comp. physiol. Psychol. 65: 118-125, 1968.

4. Bignami, G. Pharmacological influences on mating behavior in the male rat. Psychopharmacology 10: 44-58, 1966.

5. Brady, J. V., J. Boren, D. Conrad and M. Sidman. The effect of food and water deprivation upon intracranial self-stimulation. J. comp. physiol. Psychol. 50: 134-137, 1957.

6. Browne, S. G. Cantharidin poisoning due to a "blister beetle". Brit. med.J. part 2, 1290-1291, 1960.

7. Caggiula, A. R. Specificity of copulation-reward systems in the posterior hypothalamus. Proceedings of the 75th Annual Convention of the American Psychological Association 2: 125-216, 1967.

8. Caggiula, A. R. and B. G. Hoebel. "Copulation-reward site" in the posterior hypothalamus. Science 153: 1284-1285, 1966.

9. Carlton, P. L. Cholinergic mechanisms in the control of behavior by the brain. Psychol. Rev. 70: 19-39, 1963.

10. Ditman, K. Inhibition of ejaculation by chlorprothixene. Am. J. Psychiat. 120: 1004-1005, 1964.

11. Donsono, A. O., F. J. E. Stefano, A. M. Biscardi and J. Cukier. Effects of castration on hypothalamic catecholamines. $A m . J$ Physiol. 212: 737-739, 1967.

12. Drips, R. D. Preanesthetic medication. In: The Pharmacological Basis of Therapeutics, edited by Goodman, L. S. and A. Gilman, (3rd ed.), New York: Macmillan Co., pp. 57-60, 1965.

13. Fuller, $R$. Sexual changes in the male rat following chronic administration of reserpine. Nature 200: 585-586, 1963.

14. Hart, B. L. Sexual reflexes and mating behavior in the male rat. J. comp. physiol. Psychol. 64: 388-399, 1967.

15. Herberg, L. J. Seminal ejaculation following positively reinforcing electrical stimulation of the rat hypothalamus. J. comp. physiol. Psychol. 56: 679-685, 1963.

16. Herrnstein, R. J. Placebo effect in the rat. Science 138: 677-678, 1962.

17. Hess, W. R. Diencephalon: Autonomic and Extrapyramidal Functions. New York: Grune and Stratton, 1954.

18. Hoebel, B. G. and P. Teitelbaum. Hypothalamic control of feeding and self-stimulation. Science 135: 375-376, 1962.

19. Hughes, J. M. Failure to ejaculate with chlordiazepoxide. Am. J. Psychiat. 121: 610-611, 1964.

20. Jung, O. H. and E. S. Boyd. Effects of cholinergic drugs on self-stimulation response rates in rats. Am. J. Physiol. 210: 432-434, 1966.

21. Larsson, K. Non-specific stimulation and sexual behavior in the male rat. Behaviour 20: 110-114, 1963.

22. Maclean, P. D. and D. W. Ploog. Cerebral representation of penile erection. J. Neurophysiol. 25: 29-55, 1962.

23. Marriott, A. S. and P. S. J. Spencer. Effects of centrally acting drugs on exploratory behavior in rats. Pharmac. Chemother. 25: 432-441, 1965.

24. Melin, P. and J. E. Kihlstrom. Influence of oxytocin on sexual behavior in male rabbits. Endocrinology 73: 433-435, 1963.
25. Meyers, B., K. H. Roberts, R. H. Riciputi and E. F. Domino. Some effects of muscarinic cholinergic blocking drugs on behavior and the electrocorticogram. Psychopharmacology 5: 289-300, 1964.

26. Money, J. and R. Yankowitz. The sympathetic-inhibiting effects of the drug Ismelin on human male eroticism with a note on Mellaril. J. Sex Res. 3: 69-82, 1967.

27. Montanaro, $N$. and $M$. Babbini. Interaction between iminodibenzyl-derivatives or phenothiazine derivatives and methamphetamine in the rat. Psychopharmacology 7: 321-338, 1965.

28. Nickerson, $M$. Drugs inhibiting adrenergic nerves and structures innervated by them. In: The Pharmacological Basis of Therapeutics, edited by Goodman, L. S. and A. Gilman, (3rd ed.), New York: Macmillan Co., pp. 285-311, 1965.

29. Olds, J. Effects of hunger and male sex hormones on selfstimulation of the brain. J. comp. physiol. Psychol. 51: 320-324, 1958.

30. Olds, J. Brain centers and positive reinforcement. Proceedings of the XXVIIth International Congress of Psychology, Washington, D.C., Aug. 1963.

31. Olds, M. E. Facilitatory action of diazepam and chlordiazepoxide on hypothalamic reward behavior. J. comp. physiol. Psychol. 62: 136-140, 1966.

32. Poschel, B. P. H. MAO inhibiting effects on self-stimulation; their measurement and meaning. Lecture presented at the Drugs, Brain, and Behavior Seminar, University of Michigan, 1967.

33. Poschel, B. P. H. and F. W. Ninteman. Psychotropic drug effects on self-stimulation of the brain: a control for motor output. Psychol. Rep. 19: 79-82, 1966.

34. Prescott, R. G. W. Estrous cycle in the rat: effects on selfstimulation behavior. Science 152: 796-797, 1966.

35. Randall, L. O., G. A. Heise, W. Schallek, R. E. Bagdon, R. Banziger, A. Boris, R. A. Moe and W. B. Abrams. Pharmacological and clinical studies on Valium, a new psychotherapeutic agent of the benzodiazepine class. Curr. ther. Res. 3: 405-425, 1961.

36. Seevers, M. H. Opiate addiction in the monkey. II: Dilaulid in comparison with morphine, heroin, and codeine. J. Pharmac. 56: 157-165, 1936.

37. Siegel, S. Nonparametric Statistics for the Behavioral Sciences. New York: McGraw-Hill, 1956.

38. Smith, C. B. Enhancement by reserpine and a-Methyl dopa of the effects of d-amphetamine upon the locomotor activity of mice. J. Pharmac. exp. Ther. 142: 343-350, 1963.

39. Soulairac, A. and M. L. Soulairac. Action de la réserpine sur le comportement sexuel du rat mâle. J. Physiol. 44: 99-113, 1952.

40. Soulairac, M. L. Etude expérimentale des régulations hormono-nerveuses du comportement sexuel du rat mâle. $A n n$. Endoc. (Paris), 24: (suppl. to no. 3), 1-98, 1963.

41. Zimbardo, P. G. and J. Barry. III: Effects of caffeine and chlorpromazine on the sexual behavior of male rats. Science 127: 84-85, 1958. 